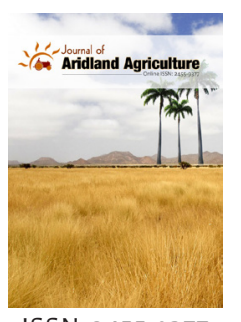

ISSN: $2455-9377$

\title{
Irrigation with municipal wastewater as a suitable solution for safflower cultivation in arid regions
}

\author{
Somayeh Baghani', Issa Piri', Abolfazl Tavassoli*, Mohammad Reza Naghavi', \\ Fatemeh Rastegaripour ${ }^{2}$
}

'Department of Agriculture, Payame Noor University, PO Box 193954697 Tehran, Iran, ${ }^{2}$ Department of Agriculture, University of Torbat Heydarieh, Torbat Heydarieh, Iran

\begin{abstract}
In order to studying effect of different manure and chemical fertilizer levels on qualitative and quantitative characteristics of safflower in condition of irrigation with municipal wastewater, an experiment was conducted as split plot basis of randomized complete design in Lakhshah region locate in Zahedan city, Iran. The treatments were comprised of two levels of irrigation, $\mathrm{W}_{1}=$ Well water and $\mathrm{W}_{2}=$ Treated wastewater, in main plots and sub plots consisted of $\mathrm{F}_{1}$ : control (without consumption of manure and chemical fertilizer), $\mathrm{F}_{2}$ : Recommended manure, $\mathrm{F}_{3}$ : Half of recommended manure and chemical fertilizer (N,P and $\mathrm{K})$, and $\mathrm{F}_{4}$ : Recommended chemical fertilizer (N, P and $\mathrm{K}$ ). The results showed that Treatment of treated wastewater had a positive and significant influence on all yield components, and the most influence was showed on 1000 seed weight. Also irrigation with wastewater significantly increase the dry and fresh yield and grain yield of safflower than ordinary water. Among the fertilizer treatments, complete treatment of chemical fertilizer $\mathrm{N}$, $\mathrm{P}$ and $\mathrm{K}$ had the greatest effect on increase of yield and grain yield components. In this experiment water treatment hadn't significant effect on accumulation of $\mathrm{Cr}$, pb, Fe and $\mathrm{Mn}$ in safflower grain, and soil. While, fertilizer treatment had only significant influence on accumulation of $\mathrm{Fe}$ and $\mathrm{Mn}$ in safflower grain, but between these treatments wasn't
saw any significant different on accumulation of $\mathrm{Cr}$ and $\mathrm{pb}$. In general, the results of this experiment showed that
\end{abstract} E-mail: Tavassoli.abolfazl@yahoo. saw an with wastewater and application of complete fertilizer with manure is recommended.
com *Corresponding Author Abolfazl Tavassoli

Received: August 17, 2021

Accepted: December 07, 202

Published: December 24, 2021

KEYWORDS: Fertilizer, oil, safflower, wastewater, yield

\section{INTRODUCTION}

Among crops, oil producing plants, including safflower, have a major role in the production of oil in the each country. Oil, as one of the main sources of protein and energy, plays a vital role in human nutrition. Given the increasing trend, consumption is due to population growth and economic improvement of the population (Vollmann and Rajcan, 2009; McKeon et al., 2016). Safflower, like other crops, requires proper nutrition for proper performance, which is unfortunately inappropriate for fertilizer use in Iran (Haghighati, 2010). Organic fertilizers are essential to sustain soil fertility and agricultural production (Mehraban, 2013). Soils of arid and semi-arid region of Iran usually lack organic matter, which reduces fertility and desirable chemical and physical properties of these soils (Roozitalab et al., 2018). This has prompted researchers to conduct extensive research on the use of organic fertilizers. Studies have shown that the addition of organic matter to soil, depending on the characteristics of the types of these substances that make them very different, has different effects on its physical, chemical and biological properties, which in most cases by optimizing these conditions, It enables the production of high-performance products both qualitatively and quantitatively (Mehraban, 2013). Organic fertilizers, such as animal fertilizers, have been popular in arable lands throughout the world. Due to the lack of organic matter in the soils of arid and semiarid regions, application of organic compounds in these areas improves soil physical, chemical and fertile properties (Mehraban, 2013). It is also one of the biggest agricultural problems in arid and semi-arid regions of available water for irrigating farms (Al-Maktoumi et al., 2021). When renewable freshwater supplies do not meet the needs of agricultural, industrial, and urban uses, human resources will inevitably be drawn to other options, such as treated wastewater, municipal wastewater, disinfected seawater and other disinfected water. In the meantime, liquid municipal wastewater is very valuable water that, due to its mineral and organic properties, can also play an important role in the fertility of agricultural land (Spellman, 2020). 
Ahmed et al., (2016) studied combining textile effluent wastewater with organic fertilizer for improved growth and productivity of wheat and soil health. In this study founded researchers that treatment with textile effluent water + organic fertilizer caused an increase of $21 \%, 45 \%, 90 \%$ and $110 \%$ in no. of grains spike-1, root length, fresh root and shoot biomass, respectively compared to the application of textile effluent water + recommended dose of NPK. Similarly, NPK contents of straw $(190 \%, 200 \%$ and $67 \%)$ and grain $(45 \%, 300 \%$ and $73 \%)$ were significantly improved in textile effluent water + organic fertilizer compared to textile effluent water + recommended dose of NPK, respectively. Moreover, microbial population was 1.5 folds more in textile effluent water + organic fertilizer compared to textile effluent water + recommended dose of NPK. In conclusion, application of textile effluent wastewater along with organic fertilizer could help to mitigate its negative impacts on crop and soil health. Akhkha et al., (2019) investigated the effect of irrigation with Al-Madinah Al-Munawwarah domestic sewage water on the desert shrub Calotropis procera. The results showed that most growth and physiological parameters were increased in response to irrigation with treated sewage waters. The levels of heavy metals in sewage water were in trace amounts.

Due to water scarcity in arid and semi-arid regions such as Iran, the use of wastewater in crop production can be considered as a reliable source of irrigation water. As a result, not only will part of the agricultural water shortage be offset, it will also prevent the adverse effects of wastewater discharge and its damage to agricultural resources and environmental pollution (Blumenthal et al., 2001). Since Zahedan is located in arid and semi-arid areas of the country, therefore, the study of the use of abnormal waters (due to dehydration) and organic fertilizers (due to soil organic matter poverty) or in other words the study of the effects of fertilizer application Organic and its combination with fertilizers and irrigation with municipal wastewater is essential. In this regard, this study aims to study the effects of chemical fertilizers on safflower quantitative and qualitative yield increase, study of the effect of livestock fertilizers and combination of chemical fertilizers on safflower quantitative and qualitative yield, study of municipal wastewater treatment in comparison Irrigation with ordinary water on increasing safflower's qualitative and quantitative yield and study of the interaction of using manure and chemical fertilizers with municipal wastewater on increasing safflower's qualitative and quantitative yield in Zahedan region of Iran.

\section{MATERIALS AND METHODS}

This research was carried out in the research field located in Lakhshak area of Zahedan in 2014-15. The test site is located at a latitude of 28 degrees 14 minutes and a longitude of 61 degrees 13 minutes east with an altitude of 1333 meters above sea level. The climate of the region is moderately temperate and according to the Coupon subdivision, the climate is warm and dry. The average annual rainfall is $150 \mathrm{~mm} / \mathrm{year}$ and the mean maximum temperature is $27.4^{\circ} \mathrm{C}$ and the minimum average is $12.3^{\circ} \mathrm{C}$.
The testing ground was a perennial fallow plot. To determine the physical and chemical properties of the soil, soil sampling was carried out from 0 to $30 \mathrm{~cm}$ from soil depths. Specimens were sent to the laboratory for physical and chemical analysis. The results are shown in tables 1 and 2. One sample of irrigation water and wastewater was also sent to the laboratory and the results of water decomposition are presented in tables 3 and 4.

This study was conducted as split plot experiment in a randomized complete block design with three replications. In this experiment, the main factor consisted of two levels of $W_{1}=$ ordinary water irrigation (without wastewater) and $\mathrm{W}_{2}=$ plant irrigation, during the whole growth period with treated wastewater of Zahedan city and sub-factor including four levels of fertilizer, $\mathrm{F}_{1}$ : no fertilizer, $\mathrm{F}_{2}$ : full application of recommended fertilizer, $\mathrm{F}_{3}$ : half application of recommended fertilizer with half recommended $\mathrm{N}, \mathrm{P}$ and $\mathrm{K}$ fertilizers, and $\mathrm{F}_{4}$ : complete application of N, P and K fertilizers, respectively. The recommended amount of manure and chemical fertilizer was determined based on the results of soil tests. Chemical analysis of manure (cow manure) used in the experiment are shown in table 5 . In this experiment, four safflowers with $99 \%$ purity were selected from Isfahan. Each block consisted of 8 plots. Each plot was designed with 6 rows of planting $3 \mathrm{~m}$ long and $50 \mathrm{~cm}$ apart. Plants were also spaced $40 \mathrm{~cm}$ apart on each row.

The tested land was crushed by plowshare plow and two times perpendicular discs on the twenty-second day of October 2014, exactly 10 days before planting, and then leveled by Lawler. Then it was carried out in order to implement the land classification scheme. After land cultivation and pre-planting, conventional fertilizer levels in the area were 60 t.ha-1, and chemical fertilizer containing $250 \mathrm{~kg} \cdot \mathrm{ha}^{-1}$ superphosphate triple, $150 \mathrm{k} \cdot \mathrm{ha}^{-1}$ potassium sulfate fertilizer and $100 \mathrm{~kg}$ nitrogen from urea source to experimental plots were added. Fertilizer was added to the respective experimental plots in two stages (stem elongation and head production) at a rate of $50 \mathrm{~kg} \cdot \mathrm{ha}^{-1}$ of urea fertilizer each time.

Sowing safflower at a depth of $3 \mathrm{~cm}$ was done manually in November 2014 with a density of 50,000 plants per hectare. Immediately after sowing, the soil was irrigated and during the growing season, irrigation was carried out once a week. To reach the desired density, thinning was performed in the 3-4 leaf stage. Weed weeding was performed in two stages (simultaneous crop thinning and stem elongation). In terms of pests, the field was exposed to housefly, aphid, bollworm, which was sprayed with a solution of 2 per 1,000 dimethoate. Ripe safflower was also harvested manually in late May 2014. For sampling from the experimental plots was removed from 6 rows with a length of $3 \mathrm{~m}$ per plot, two side lines on each side and $50 \mathrm{~cm}$ above and below each row as margins. Finally, four midlines of $2 \mathrm{~m}$ each were selected to determine all the agronomic traits measured in this experiment.

Table 1: Soil physical properties of the experiment place

\begin{tabular}{llcccc}
\hline $\begin{array}{l}\text { Soil depth } \\
(\mathrm{cm})\end{array}$ & $\begin{array}{l}\text { Sample } \\
\text { characteristics }\end{array}$ & $\begin{array}{c}\text { Clay } \\
\text { percentage }\end{array}$ & $\begin{array}{c}\text { Sand } \\
\text { percentage }\end{array}$ & $\begin{array}{c}\text { Silt } \\
\text { percentage }\end{array}$ & $\begin{array}{l}\text { Soil } \\
\text { texture }\end{array}$ \\
\hline $0-30$ & Desired sample & 24 & 49 & 26 & $\begin{array}{l}\text { Loam } \\
\text { Sand }\end{array}$ \\
\hline
\end{tabular}


Table 2: Soil chemical properties of the experiment place

\begin{tabular}{|c|c|c|c|c|c|c|c|c|c|c|}
\hline $\begin{array}{l}\text { Soil depth } \\
\text { (cm) }\end{array}$ & $\begin{array}{l}\text { Electrical conductivity } \\
\left.\text { (ds. } \mathrm{m}^{-1}\right)\end{array}$ & Acidity of Saturated mud & $\begin{array}{l}\text { Organic carbon } \\
\text { (\%) }\end{array}$ & $\begin{array}{l}\text { Total nitrogen } \\
(\%)\end{array}$ & $\begin{array}{c}\text { Phosphorus } \\
\text { absorbable } \\
\text { (ppm) }\end{array}$ & $\begin{array}{c}\text { potassium } \\
\text { absorbable } \\
\text { (ppm) }\end{array}$ & $\begin{array}{c}\mathrm{Cr} \\
(\mathrm{ppm})\end{array}$ & $\begin{array}{c}\mathrm{Fe} \\
(\mathrm{ppm})\end{array}$ & $\begin{array}{c}\mathrm{pb} \\
(\mathrm{ppm})\end{array}$ & $\begin{array}{c}\mathrm{Mn} \\
\text { (ppm) }\end{array}$ \\
\hline $0-30$ & 2.89 & 7.42 & 0.56 & 0.46 & 9.21 & 299 & 0.0084 & 0.0190 & 0.0210 & 0.0621 \\
\hline
\end{tabular}

Table 3: Water physical and chemical properties used in the experiment

\begin{tabular}{|c|c|c|c|c|c|c|c|c|c|c|c|c|c|}
\hline $\begin{array}{l}\text { EC } \\
\text { Us/cm }\end{array}$ & $\mathrm{pH}$ & $\mathrm{CO}_{3}$ & $\mathrm{HCO}_{3}$ & $\mathrm{Ce}$ & $\mathrm{SO}_{4}$ & sum of the anions & $\mathrm{Ca}$ & $\mathrm{Mg}$ & $\mathrm{Na}$ & $\begin{array}{c}\text { TDS } \\
\left(\mathrm{mg}^{\prime} \text { lit }^{-1}\right)\end{array}$ & SAR & $\begin{array}{l}\text { SSP } \\
(\%)\end{array}$ & Water class \\
\hline 2378 & 7.34 & 0 & 7.7 & 10.6 & 11.5 & 29.7 & 11.5 & 7.7 & 12.1 & 1256 & 3.1 & 31.4 & C4-SI \\
\hline
\end{tabular}

Table 4: Wastewater physical and chemical properties used in the experiment

\begin{tabular}{|c|c|c|c|c|c|c|c|c|c|c|c|c|}
\hline $\begin{array}{l}\mathrm{EC} \\
\mathrm{Us} / \mathrm{cm}\end{array}$ & $\mathrm{pH}$ & $\mathrm{CO}_{3}$ & $\mathrm{HCO}_{3}$ & $\mathrm{Ce}$ & $\mathrm{SO}_{4}$ & sum of the anions & $\mathrm{Ca}$ & $\mathrm{Mg}$ & $\mathrm{Na}$ & $\begin{array}{c}\text { TDS } \\
\left(\mathrm{mg}^{2} \mathrm{lit}^{-1}\right)\end{array}$ & SAR & $\begin{array}{l}\text { SSP } \\
(\%)\end{array}$ \\
\hline 2519 & 7.82 & 0 & 7.8 & 11.3 & 11.8 & 32.9 & 12.4 & 7.8 & 12.7 & 1344 & 3.3 & 38.2 \\
\hline
\end{tabular}

Table 5: Chemical analysis of manure (cow manure) used in the experiment

\begin{tabular}{lccccc}
\hline Total Nitrogen (\%) & Total Phosphorus (\%) & Total Potassium (\%) & $\begin{array}{c}\text { Fe } \\
\left(\mathrm{mg}^{\circ} \mathrm{kg}^{-1}\right)\end{array}$ & $\begin{array}{c}\mathrm{Zn} \\
\left(\mathrm{mg}^{\mathrm{kg}} \mathrm{kg}^{-1}\right)\end{array}$ & $\begin{array}{c}\mathrm{Mn} \\
\left(\mathrm{mg} \cdot \mathrm{kg}^{-1}\right)\end{array}$ \\
\hline 20.06 & 7.34 & 1.56 & 6998.10 & 58.00 & 354.08 \\
\hline
\end{tabular}

For each of the traits evaluated in the experiment, five random samples were taken from each plot and final values were obtained from averaging the corresponding values. To measure plant height, 5 plants were randomly selected from each plot and plant height from crown to head was measured in centimeters and averages were calculated. Also, number of branches, number of heads per plant and number of grains per head were determined. In addition, five plants were randomly selected from each plot for calculation of 1000-grain weight, and 200 seeds were randomly selected after drilling, and their weight was measured and multiplied by five. Sensitive scales with a maximum capacity of 300 grams and an accuracy of 0.001 grams were used to determine 1000-grain weight.

To measure the fresh and dry forage yield of the plant during sampling, the samples were weighed by scales and then the safflower samples were transferred to an oven at $70{ }^{\circ} \mathrm{C}$ for 48 hours and finally their dry weight was calculated per unit area. $\mathrm{Also}$, in order to calculate the economic yield of grain, a sample of four meters long $\left(3.6 \mathrm{~m}^{2}\right)$ was taken from three middle lines of each plot (second, third and fourth planting lines) and the yield of each plot was calculated in $\mathrm{kg} / \mathrm{ha}$. The percentage and yield of seed oil were also measured by grinding 10 grams of seeds to extract the oil and placed in a Soxhlet extractor apparatus, and then 300cc benzene was added. The lubrication process took 2-3 hours. Finally, to separate the solvent from the extracted oil, the mixture was placed in rotary for 20 minutes. Then, the oil container was placed in a cool, dark place for 48 hours to remove solvent residues. Finally, the amount of extracted oil was weighted and then the percentage of oil was calculated. Oil yield was also calculated from the percentage of oil with grain yield.

Finally, SAS software was used to analyze the variance and compare the mean data of raw plots and also Excel software was used to draw graphs. Means were compared by Duncan's multiple range tests at the $5 \%$ level of probability.

\section{RESULTS AND DISCUSSION}

\section{Plant Height}

The results of analysis of variance showed that plant height at the end of growing season was significantly at $5 \%$ probability level affected by experimental treatments (Table 6). Comparison of the mean irrigation treatments showed that irrigation with treated municipal wastewater increased plant height by $13.9 \%$ (Table 7). Shahalam et al., (1998) in a study on 3 different crop growths attributed these three crops to irrigation with municipal wastewater due to the presence of appropriate nutrients such as nitrogen, phosphorus and potassium in the wastewater.

Comparison of mean fertilizer treatments showed that the highest plant height was obtained from the treatment of a mixture of manure and chemical fertilizers as well as the chemical fertilizer alone, and the other fertilizer treatments had no significant effect on plant height (Table 7). According to the results, it was found that in order to reach maximum height; an optimum level of fertilizers is needed. So, in the treatments where the fertilizer was applied, the plant height was significantly higher than the other treatments (Table 7). In this experiment, not using fertilizer decreased the height, which may have a negative effect on height increase due to disturbance of nutritional balance (Han et al., 2016).

\section{Number of Branches}

The number of branches in the plant was significantly affected by irrigation treatments and different levels of fertilizer 
(Table 6). Irrigation with treated municipal wastewater increased the number of branches by $18.07 \%$ in comparison with normal water irrigation (Table 7). According to the results of the experiment, increasing the plant height due to irrigation with treated municipal wastewater can be considered as the most important factor in increasing the number of branches. In this regard, as shown in the correlation coefficients table (Table 8), there is a significant and positive correlation between plant height and number of branches.

Among the fertilizer treatments, it was observed that in the treatment of organic and chemical fertilizers, the number of branches per plant was significantly higher than the treatments without fertilizer application. Among all treatments, chemical fertilizer mixed with manure had the greatest effect on the number of sub-branches compared to other fertilizer treatments. Chemical fertilizer treatment alone was in second place but there was no statistically significant difference between the two treatments (Table 7). The most important reason for this may be to improve plant growth under nutrient availability and further stem growth (Rathke et al., 2005).

\section{Components of Grain Yield}

The results of statistical analysis of the data in table 6 show that the effect of irrigation and fertilizer treatments on the number of heads per plant, number of grains per head and 1000-grain weight was significant. Comparison of mean data based on Duncan's multiple range test showed that the use of municipal wastewater compared to conventional water treatment effectively improved all components of grain yield (Table 7). Among the components of grain yield, the greatest effect of wastewater was related to 1000 -grain weight, which was $23.90 \%$ more than conventional irrigation. After 1000-grain weight, the number of heads per plant (14.07\%) and the number of grains per head $(6.98 \%)$ had the highest increase, respectively (Table 7). Khaskhoussy et al., (2013) showed that irrigation with treated municipal wastewater resulted in a greater increase in 1000-grain weight than other components of maize yield compared to normal water. Also, be noted that one of the reasons for the increase in 1000-grain weight may be the amount of chlorophyll in the leaves during the grain filling

Table 6: Analysis of variance of irrigation and fertilizer treatments on studied traits

\begin{tabular}{|c|c|c|c|c|c|c|}
\hline \multirow[t]{2}{*}{ Source of Variation } & \multirow[t]{2}{*}{$\begin{array}{l}\text { Degree of } \\
\text { freedom (df) }\end{array}$} & Plant height & $\begin{array}{c}\text { Number of branches } \\
\text { per plant }\end{array}$ & $\begin{array}{c}\text { Number of heads } \\
\text { per plant }\end{array}$ & $\begin{array}{c}\text { Number seed per } \\
\text { head }\end{array}$ & $\begin{array}{l}1000 \text { Seed } \\
\text { weight }\end{array}$ \\
\hline & & \multicolumn{5}{|c|}{ Mean of Squares } \\
\hline Replication & 2 & $0.421^{\mathrm{ns}}$ & $0.893^{\text {ns }}$ & $0.39^{\text {ns }}$ & $4.053^{\text {ns }}$ & $1374.05^{\text {ns }}$ \\
\hline Irrigation & 1 & $14.445^{*}$ & $21.265^{*}$ & $7.301 * *$ & $75.05 * *$ & $32958.39 * *$ \\
\hline Irrigation Error & 2 & 4.089 & 10.715 & 0.540 & 30.877 & 1202.90 \\
\hline Fertilizer & 3 & 0.924 & $5.439 *$ & $3.403 * *$ & $22.691 *$ & $2990.98 * *$ \\
\hline Interaction & 3 & $1.911^{\mathrm{ns}}$ & $9.080^{\text {ns }}$ & $2.272^{\mathrm{ns}}$ & $24.265^{\mathrm{ns}}$ & $1105.71^{\mathrm{ns}}$ \\
\hline Total Error & 12 & 1.001 & 2.359 & 0.533 & 7.431 & 596.012 \\
\hline Coefficient of Variation (\%) & - & 7.32 & 8.91 & 9.36 & 14.22 & 7.09 \\
\hline
\end{tabular}

$* *,{ }^{*}$, and ${ }^{n . s}$ are significant at $1 \%, 5 \%$ probability level and non-significant respectively

Table 7: Mean comparison of studied traits affected by irrigation and manure and chemical fertilizers

\begin{tabular}{|c|c|c|c|c|c|c|c|}
\hline Treatment & $\begin{array}{l}\text { Plant height } \\
\text { (cm) }\end{array}$ & $\begin{array}{c}\text { Number of } \\
\text { branches per plant }\end{array}$ & $\begin{array}{c}\text { Number of } \\
\text { heads per plant }\end{array}$ & $\begin{array}{c}\text { Number seed } \\
\text { per head }\end{array}$ & $\begin{array}{l}100 \text { Seed } \\
\text { weight }(g)\end{array}$ & Oil Percentage & $\begin{array}{l}\text { Oil yield } \\
\left(\mathrm{kg} \cdot \mathrm{ha}^{-1}\right)\end{array}$ \\
\hline \multicolumn{8}{|l|}{ Irrigation } \\
\hline Normal Water & $109.73 b$ & $15.37 b$ & $66.43 b$ & $406.72 b$ & $17.32 \mathrm{~b}$ & $8.41 \mathrm{a}$ & $58.80 \mathrm{~b}$ \\
\hline Municipal wastewater & $126.41 a$ & $18.76 a$ & $77.31 \mathrm{a}$ & $437.26 a$ & $22.76 a$ & $9.00 \mathrm{a}$ & $71.23 \mathrm{a}$ \\
\hline \multicolumn{8}{|l|}{ Fertilizer levels } \\
\hline No use of fertilizer & $95.46 c$ & $13.52 \mathrm{c}$ & $65.32 b$ & $356.26 c$ & $17.02 b$ & $7.99 \mathrm{~b}$ & $48.56 \mathrm{C}$ \\
\hline Recommended manure & $109.36 b$ & $16.35 b$ & $69.48 b$ & $400.32 b$ & $22.91 a$ & $8.46 a b$ & $60.35 b$ \\
\hline Recommended chemical fertilizer & $124.31 \mathrm{a}$ & $20.41 a$ & $76.18 a$ & $409.76 b$ & $23.00 a$ & $9.08 \mathrm{a}$ & $69.48 \mathrm{a}$ \\
\hline $\begin{array}{l}\text { Half the recommended manure } \\
\text { and chemical fertilizer }\end{array}$ & $127.73 a$ & $21.74 a$ & $75.29 a$ & $428.54 a$ & $23.09 a$ & $9.20 \mathrm{a}$ & $72.11 \mathrm{a}$ \\
\hline
\end{tabular}

Similar letters in each column indicate that there is no significant difference between them

Table 8: Correlation coefficients between yield and measured traits in irrigation conditions with municipal wastewater

\begin{tabular}{|c|c|c|c|c|c|c|c|}
\hline Traits & Plant height & $\begin{array}{c}\text { Number of } \\
\text { branches Per Plant }\end{array}$ & $\begin{array}{c}\text { Number of } \\
\text { heads per plant }\end{array}$ & $\begin{array}{c}\text { Number of } \\
\text { seed per head }\end{array}$ & $\begin{array}{c}1000 \text { seed } \\
\text { weight }\end{array}$ & $\begin{array}{l}\text { Dry forage } \\
\text { yield }\end{array}$ & Seed yield \\
\hline Plant height & 1 & & & & & & \\
\hline Number of branches per Plant & $0.66 * *$ & 1 & & & & & \\
\hline Number of heads per plant & $0.63 * *$ & 0.10 & 1 & & & & \\
\hline Number of seed per head & $0.80 * *$ & $0.53 *$ & -0.27 & 1 & & & \\
\hline Seed 1000 weight & 0.31 & -0.32 & $-0.31 *$ & $-0.65^{*}$ & 1 & & \\
\hline Dry forage yield & $0.96 * *$ & $0.92 * *$ & $0.73 *$ & $0.77 * *$ & $0.78 * *$ & 1 & \\
\hline Seed yield & 0.35 & $0.72 * *$ & $0.86 * *$ & $0.93 * *$ & $0.89 * *$ & $0.72 * *$ & 1 \\
\hline
\end{tabular}

* and ** are significant at $5 \%$ and $1 \%$ probability respectively 
stage. Irrigation with water sewage resulted in a $50 \%$ increase in leaf chlorophyll $a, b$ content compared to conventional irrigation (Zeid and Abou El Ghate, 2007).

Comparison of mean fertilizer treatments showed that combined application of manure and fertilizers $\mathrm{K}, \mathrm{P}$ and $\mathrm{N}$ had the most effect on all grain yield components compared to other fertilizer treatments (Table 7). Manure is thought to improve the soil structure and provide the necessary conditions for the plant to absorb more of the elements present in the effluent, which ultimately improves safflower yield components. It has been reported that due to balanced nutrient consumption, the number of grains, 1000-grain weight and, ultimately, grain yield in crops increased (Marschener, 1995).

\section{Fresh and Dry Forage Yield}

The effect of irrigation and fertilizer treatment on fresh and dry forage yield of safflower was significant. Interaction of irrigation and fertilizer treatments was significant for fresh and dry forage yield of safflower (Table 9). Comparison of mean interaction effects showed that the highest fresh and dry forage yields were related to irrigation with treated wastewater and mixture of manure and chemical fertilizers $\left(\mathrm{W}_{2} \mathrm{~F}_{4}\right)$ which were $4385.09 \mathrm{~kg} \cdot \mathrm{ha}^{-1}$ and $3167.05 \mathrm{~kg} \cdot \mathrm{ha}^{-1}$, respectively. Also, the lowest values of these traits were obtained from $\mathrm{W}_{1} \mathrm{~F}_{1}$ irrigation treatments (2870.14 14 kg.ha-1 for fresh forage and $2004.51 \mathrm{~kg}$. $h^{-1}$ for dry forage yield). (Figures 1 and 2). Increased fresh and dry forage yield of safflower can be attributed to the presence of appropriate amounts of nutrients such as nitrogen, phosphorus and potassium in the wastewater. Mohammad Rusan and Ayadi (2013) reported that irrigation with wastewater at all growth stages resulted in the highest biological yield of maize. Similar results have been reported by Tavassoli et al. (2010) on maize. The higher yield of fresh and dry forage in the combination of manure and chemical fertilizer application can be attributed to the increase in soil organic matter content through the application of manure, which improves soil structure and increases soil moisture content. On the other hand, chemical fertilizers have been able to improve the growth and yield of the crop compared to other treatments by increasing the nutrient availability of the plant. Similar results have been reported in the study of the effects of chemical, organic fertilizers and their integration on the quantitative and qualitative characteristics of maize (Mahmood et al., 2017).

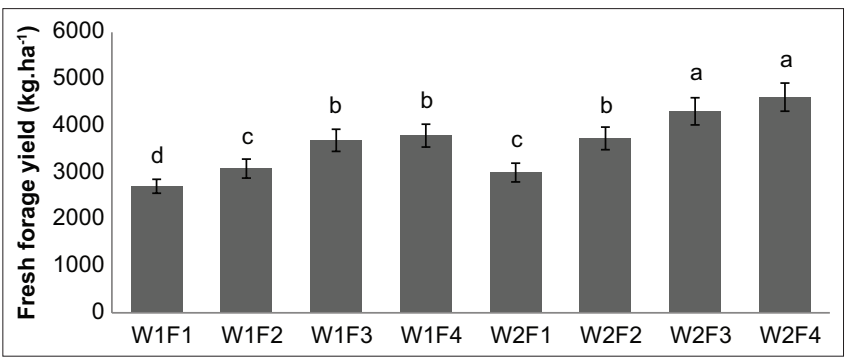

Figure 1: Mean comparison of the interaction effect of irrigation and fertilizer on fresh forage yield of safflower

\section{Seed Yield}

According to the statistical analysis of the data, both irrigation and fertilizer treatments and their interactions had a significant effect at 5\% probability level on safflower seed yield (Table 9). Comparison of mean interaction effects of irrigation and fertilizer treatments also showed that the highest and lowest grain yield were obtained from the treatments with treated wastewater with half application of chemical fertilizers $\left(\mathrm{W}_{2} \mathrm{~F}_{4}\right)$ and normal irrigation without fertilizer $\left(\mathrm{W}_{1} \mathrm{~F}_{1}\right)$, respectively (Figure 3). As can be seen in the figure, even if no manure or chemical fertilizer was used and only the wastewater was used, safflower seed yield would increase by $65.01 \mathrm{~kg} \cdot \mathrm{ha}^{-1}$ compared to conventional irrigation. Increasing the yield of safflower seeds in irrigation with municipal wastewater can also be attributed to the presence of appropriate nutrients such as nitrogen, phosphorus and potassium in the wastewater (Nasri et al., 2012). Tavassoli et al. (2010) reported that maize grain yield showed a $39.9 \%$ increase in irrigation with municipal wastewater compared to normal water irrigation. The positive effect of fertilizers on soil structure and increasing soil organic matter content as well as increasing accessibility of nutrients to the plant through the use of chemical fertilizers have been the most important reasons for improving grain yield under these treatments. Mahmood et al., (2017) showed that combined use of manure and chemical fertilizers significantly increased maize grain yield. In this study, it was observed that single application of manure showed lower grain yield compared to mixed manure and chemical fertilizer application. Manures, although they contain good amounts of nutrients such as nitrogen and to some extent micronutrients, but the low grain yield increase during their use compared to chemical fertilizers may be due to a decrease in the uptake of these elements by plants. Pimentel (1993) stated that in the first year, only $40 \%$ of the nitrogen

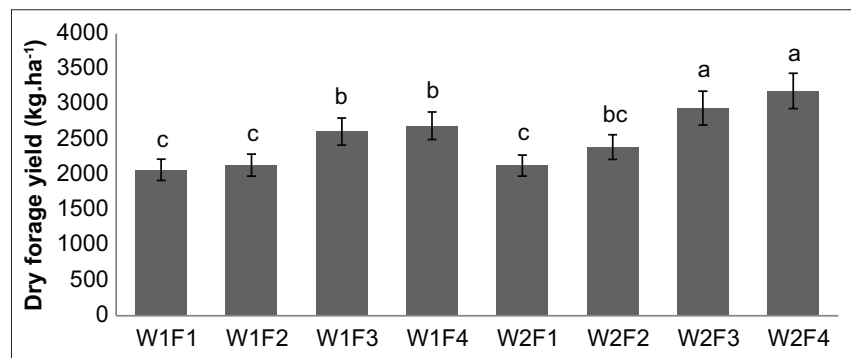

Figure 2: Mean comparison of the interaction effect of irrigation and fertilizer on dry forage yield of safflower



Figure 3: Mean comparison of the interaction effect of irrigation and fertilizer on seed yield of safflower 
fertilizer application would be absorbed by plants. Khaskhoussy et al., (2013) also showed in an experiment that maize grain yield was increased by the use of wastewater.

\section{Oil Percentage and Seed Oil Yield}

According to the analysis of variance, irrigation had no significant effect on seed oil percentage, but the effect of fertilizer treatments on seed oil percentage was significant (Table 9). The highest seed oil concentration was obtained from the combination of manure and chemical fertilizer treatment and no fertilizer treatment resulted in a significant decrease in seed oil percentage (Table 7). These results are similar to previous reports (Haghighati, 2010). Sharifi et al., (2017) found that the percentage of oil affected by the levels of fertilizer and the consumption of fertilizer increased the percentage of oil compared to not using it.

According to the analysis of variance table, irrigation and fertilizer had significant effect at $1 \%$ probability level for seed oil yield (Table 9). Considering that oil yield is calculated by multiplying the oil percentage by grain yield (Sampaio et al., 2017) and because in this experiment the highest oil percentage and highest grain yield were obtained from irrigation treatment with municipal wastewater and combined fertilizer and chemical fertilizer use, therefore, the highest oil yield was obtained from the same treatment (Table 7).

\section{Seed Mineral Element}

Analysis of variance showed that the treated municipal wastewater had no significant effect on the concentrations of $\mathrm{Cr}, \mathrm{pb}, \mathrm{Fe}$ and $\mathrm{Mn}$ (Table 10). Given that the wastewater used in this experiment was municipal wastewater and the wastewater of industrial plants and industrial settlements was not mixed with it, the above results were expected. However, there are other factors that can greatly affect the ability of these elements to be absorbed by the plant, including soil $\mathrm{pH}$, available soil moisture and the type of crop that can be effective in the accumulation of these elements in the plant (Tavassoli et al., 2010).

Soil pH basically determines the behavior and availability of plants to the micro elements in the soil. The availability of heavy metals has an inverse relationship with soil pH (Khan et al., 2013). Mohammad Rusan and Ayadi (2004) also showed that concentrations of $\mathrm{Fe}, \mathrm{Mn}, \mathrm{Zn}$ and $\mathrm{Cu}$ in corn affected by treated wastewater treatment were insignificant. Khan et al., (2013) measured the increase in heavy metal accumulation in wheat affected by municipal wastewater. The results showed that the concentration of heavy metals in maize grain was very low under irrigation with municipal wastewater.

The effect of manure and chemical fertilizers on the concentration of the $\mathrm{Cr}$, pb, Fe and Mn elements was not statistically significant. The interaction between fertilizer use and municipal wastewater treatment also had no significant effect on the above traits (Table 10).

\section{Soil Mineral Elements}

Results of analysis of variance showed that the amount of Cd, $\mathrm{Pb}, \mathrm{Fe}$ and $\mathrm{Mn}$ in soil was not affected by irrigation treatment and there was no significant difference between treatments (Table 10). Table 11 shows the mean concentrations for soil minerals in the treatments. Comparison of Duncan's method

Table 9: Analysis of variance of irrigation and fertilizer treatments on studied traits

\begin{tabular}{|c|c|c|c|c|c|c|}
\hline \multirow[t]{2}{*}{ Source of Variation } & \multirow{2}{*}{$\begin{array}{l}\text { Degree of } \\
\text { freedom (df) }\end{array}$} & Fresh forage yield & Dry forage yield & Seed yield & Oil Percentage & Oil yield \\
\hline & & \multicolumn{5}{|c|}{ Mean of Squares } \\
\hline Replication & 2 & $0.76^{\text {ns }}$ & $14.461^{\mathrm{ns}}$ & $4385.02^{\text {ns }}$ & $3.30^{\mathrm{ns}}$ & $48.30^{\text {ns }}$ \\
\hline Irrigation & 1 & $11.427 * *$ & $2117.640 * *$ & $566041.32 * *$ & $1.222^{\mathrm{ns}}$ & $34.77 * *$ \\
\hline Irrigation Error & 2 & 0.911 & 83.941 & 17219.2 & 0.547 & 3.07 \\
\hline Fertilizer & 3 & $8.631 * *$ & $142.730 * *$ & $51014.47 * *$ & $4.001 * *$ & $8.12 * *$ \\
\hline Interaction & 3 & $5.019 *$ & $159.977 * *$ & $30794.6 *$ & $0.550^{\text {n.s }}$ & $4.31^{n . s}$ \\
\hline Total Error & 12 & 0.866 & 81.402 & 7371.73 & 0.249 & 2.11 \\
\hline Coefficient of Variation (\%) & - & 8.44 & 7.01 & 11.52 & 21.01 & 8.55 \\
\hline
\end{tabular}

${ }^{* *},{ }^{*}$, and ${ }^{n . s}$ are significant at $1 \%, 5 \%$ probability level and non-significant respectively

Table 10: Analysis of variance of irrigation and fertilizer treatments on content of seed and soil mineral elements

\begin{tabular}{|c|c|c|c|c|c|c|c|c|c|}
\hline \multirow[t]{3}{*}{ Source of Variation } & \multirow{3}{*}{$\begin{array}{l}\text { Degree of } \\
\text { freedom (df) }\end{array}$} & $\mathrm{Cr}$ & $\mathrm{pb}$ & $\mathrm{Fe}$ & $\mathrm{Mn}$ & $\mathrm{Cr}$ & $\mathrm{pb}$ & $\mathrm{Fe}$ & $\mathrm{Mn}$ \\
\hline & & \multicolumn{4}{|c|}{ Seed } & \multicolumn{4}{|c|}{ Soil } \\
\hline & & \multicolumn{8}{|c|}{ Mean of Squares } \\
\hline Replication & 2 & $0.011^{\mathrm{ns}}$ & $0.007^{\text {ns }}$ & $0.02^{\text {ns }}$ & $0.006^{\text {ns }}$ & $0.023^{\text {ns }}$ & $0.460^{\text {ns }}$ & $0.2405^{\text {ns }}$ & $0.7130^{\text {ns }}$ \\
\hline Irrigation & 1 & $0.0004^{\mathrm{ns}}$ & $0.0004^{\mathrm{ns}}$ & $0.003^{\text {ns }}$ & $0.005^{\mathrm{ns}}$ & $0.0032^{\text {ns }}$ & $0.0323^{\text {ns }}$ & $0.105^{\mathrm{ns}}$ & $0.2581^{\mathrm{ns}}$ \\
\hline Irrigation Error & 2 & 0.037 & 0.001 & 0.002 & 0.00003 & 0.041 & 0.5692 & 0.0085 & 0.7965 \\
\hline Fertilizer & 3 & $0.006^{\text {ns }}$ & $0.01 \mathrm{~ns}$ & $0.008^{\text {ns }}$ & $0.005^{\mathrm{ns}}$ & $0.010^{\text {ns }}$ & $0.0250 *$ & $0.878^{\text {ns }}$ & $0.1044^{*}$ \\
\hline Interaction & 3 & $0.031^{\mathrm{ns}}$ & $0.018^{\mathrm{ns}}$ & $0.011^{\mathrm{ns}}$ & $0.003^{n s}$ & $0.052^{\mathrm{ns}}$ & $0.0273 *$ & $0.0353 *$ & $0.0084 * *$ \\
\hline Total Error & 12 & 0.024 & 0.007 & 0.0370 & 0.002 & 0.073 & 0.647 & 0.0370 & 0.0447 \\
\hline Coefficient of Variation (\%) & - & 23.21 & 26.75 & 19.89 & 17.41 & 16.91 & 17.82 & 9.25 & 11.41 \\
\hline
\end{tabular}

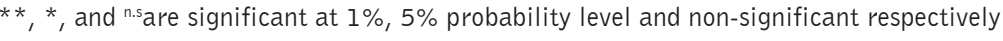


Table 11: Mean comparison mineral elements of seed and soil under irrigation and manure and chemical fertilizers

\begin{tabular}{|c|c|c|c|c|c|c|c|c|}
\hline \multirow[t]{2}{*}{ Treatment } & $\begin{array}{c}\mathrm{Cr} \\
(\mathrm{ppm})\end{array}$ & $\begin{array}{c}\mathrm{Fe} \\
(\mathrm{ppm})\end{array}$ & $\begin{array}{c}\mathrm{pb} \\
(\mathrm{ppm})\end{array}$ & $\begin{array}{c}\mathrm{Mn} \\
(\mathrm{ppm})\end{array}$ & $\begin{array}{c}\mathrm{Cr} \\
(\mathrm{ppm})\end{array}$ & $\begin{array}{c}\mathrm{pb} \\
(\mathrm{ppm})\end{array}$ & $\begin{array}{c}\mathrm{Fe} \\
(\mathrm{ppm})\end{array}$ & $\begin{array}{c}\mathrm{Mn} \\
(\mathrm{ppm})\end{array}$ \\
\hline & \multicolumn{4}{|c|}{ Seed } & \multicolumn{4}{|c|}{ Soil } \\
\hline \multicolumn{9}{|l|}{ Irrigation } \\
\hline Normal Water & $\mathrm{a} 0.0071$ & $0.0185 a$ & $0.0199 a$ & $0.0581 a$ & $0.0093 a$ & $0.0200 \mathrm{a}$ & $0.0237 a$ & $0.0673 a$ \\
\hline Municipal wastewater & $0.0075 a$ & $0.0188 a$ & $0.0201 a$ & $0.0592 a$ & $0.0099 a$ & $0.0210 a$ & $0.0243 a$ & $0.0684 a$ \\
\hline \multicolumn{9}{|l|}{ Fertilizer levels } \\
\hline No use of fertilizer & $0.0067 a$ & $0.0179 a$ & $0.0184 a$ & $0.0573 a$ & $0.0084 a$ & $0.0190 a$ & $0.0210 c$ & $0.0621 \mathrm{~b}$ \\
\hline Recommended manure & $0.0072 \mathrm{a}$ & $0.0184 a$ & $0.0199 a$ & $0.0584 a$ & $0.0091 a$ & $0.0197 a$ & $0.0242 a$ & $0.0679 a$ \\
\hline Recommended chemical fertilizer & $0.0070 \mathrm{a}$ & $0.0184 a$ & $0.0194 a$ & $0.0578 a$ & $0.0088 a$ & $0.0194 a$ & $0.0228 b$ & $0.0677 a$ \\
\hline Half the recommended manure and chemical fertilizer & $0.0072 \mathrm{a}$ & $0.0184 a$ & $0.0195 a$ & $0.0579 a$ & $0.0090 \mathrm{a}$ & $0.0195 a$ & $0.0239 a$ & $0.0677 a$ \\
\hline
\end{tabular}

Similar letters in each column indicate that there is no significant difference between them

showed that there was no significant difference between treatments. Due to the low concentration of heavy metals in wastewater, as well as the low concentration of these elements in the experimental field soil, no increase in the concentration of mineral elements was observed in this experiment. But fertilizer treatment had a significant effect on Fe and Mn concentrations, but no significant differences were observed between fertilizer treatments for $\mathrm{Cd}$ and $\mathrm{Pb}$ (Table 11). Application of fertilizers, plant residues and native rocks, and soil factors including soil acidity, type and amount of clay, amount of organic matter, redox potential, soil solution composition are the most important factors affecting the accumulation of $\mathrm{Fe}$ and $\mathrm{Mn}$ in soil are counted (Ohshiro et al., 2016).

Organic fertilizers, in addition to high nutrients, can meet at least part of the plant's needs for $\mathrm{Fe}$ and $\mathrm{Mn}$ and can be used as a complete fertilizer. Numerous reports on the elimination of nutrient deficiencies by manure (Khan et al., 2013) and wastewater (Khaskhoussy et al., 2013) are available. Most of the heavy metals in the upper layers of the soil are combined with organic matter and form strong soil complexes. Organic matter due to its high cation exchange capacity and its ability to complex with heavy metals accumulate these elements in the upper layers of the soil (Khan et al., 2013). Lindsay (1992) observed in a study that the mixing of organic matter with mineral compounds increased the efficiency of these substances in plant nutrition. Lebrun et al., (2021) showed that mixing of iron sulfate with poultry manure had a significant effect on eliminating iron deficiency of Phaseolus vulgaris L. It has been suggested that the use of organic fertilizers to increase iron solubility of mineral compounds can be useful (Day and Tucker, 1997). Almas et al. (2000) also reported that the addition of organic matter resulted in the solubility of zinc and cadmium by the formation of a metal-organic complex.

\section{Simple Correlation between Studied Safflower Traits in Irrigation Conditions with Municipal Wastewater}

In order to investigate the relationship between yield traits and yield components of safflower in this experiment, simple correlation between these traits was calculated using SAS software, the results of which are presented in table 8 . There was a significant positive correlation between fresh and dry forage yield with plant height, stem diameter, number of branches, number of heads, 1000-grain weight and grain yield. This shows a good correlation between photosynthetic efficiency and grain yield, with plants having high grain yields that accumulate more photosynthetic material in their organs. There was a significant negative relationship between forage yield or harvest index (Table 8). Gholipour (2013) reported that grain yield was positively and highly correlated with number of grains per head, 1000-grain weight, and forage yield of safflower. Other reports on the study of different safflower cultivars in dry conditions showed significant differences between them in terms of grain yield, oil content, number of heads per plant, 1000 seed weight and plant height (Haghighati, 2010). It has also been shown that there is a negative correlation between 1000-grain weight and number of seeds per head in safflower, indicating a compensatory role of 1000-grain weight in the distribution of nutrients distribution between the number of seeds (Haghighati, 2010). Therefore, this issue illustrates the contribution of other components of grain yield in justifying the grain yield per head. Any crop changes to increase the two traits, number of heads per plant and 1000-seed weight will increase grain yield.

\section{CONCLUSION}

The results of this study showed that irrigation with municipal wastewater treatment compared to irrigation with ordinary water resulted in increased yield of forage, seed and safflower oil. Fertilizer application with chemical fertilizer was higher in all quantitative traits and safflower oil yield compared to single and non-fertilizer treatments. In fact, it was observed in this experiment that irrigation with wastewater combined with the application of manure combined with chemical fertilizers can directly increase the yield and yield of safflower by increasing the nutrient availability of the plant. In general, the results of this experiment showed that for achieving the highest quantitative and qualitative yield of safflower in Zahedan of Iran, irrigation with wastewater and complete fertilizer application with manure is recommended to farmers in the area.

\section{ACKNOWLEDGMENTS}

The financial support of this project was done by the research grant of Payame Noor University (PNU) under support of Ministry of Science, Research and Technology's information Iran. 


\section{REFERENCES}

Ahmed, F., Arshad, M., Ditta, A., Hussain, A., Naveed, M., Hasnain, M., \& Nazir, Q. (2016). Combining Textile Effluent Wastewater with Organic Fertilizer for Improved Growth and Productivity of Wheat and Soil Health. Journal of Environmental and Agricultural Sciences, 8, 14-20.

Akhkha, A., Al-Radaddi, E. S., \& Al-Shoaibi, A. K. (2019). The impact of treated and untreated municipal sewage water on growth and physiology of the desert plant Calotropis procera. Journal of Taibah University for Science, 13(1), 754-764. https://doi.org/10.1080/1658 3655.2019.1605650

Alizadeh, A. M., Bazari, E., Velayati, S., Hasheminia, M., \& Yaghmaie, K. (2001). Irrigation of corn with wastewater. In: Ragab, G.P., A.J. Chang, S. Nairizi, and A. Hamby. (Eds). 52 ${ }^{\text {nd }} / C / D$, International Workshop on Wastewater Reuse and Management (pp. 137-146). Seoul, Korea.

Al-Maktoumi, A., Abdalla, O., Kacimov, A., Zekri, S., Chen, M., Al-Hosni, T., \& Madani, K. (2021). Water resources in arid lands: management and sustainability. (pp. 385) Springer Press.

Almas, A. R., Singh, B. R., \& McBride, M. B. (2000). Solubility and liability of cadmium and zinc in two soil treated with organic matter. Soil Science, 165, 250-259. https://doi.org/10.1097/00010694-20000300000007

Blumenthal, A. P., Ruzi-Palacio, A., \& Mara, G. D. (2001). Guidelines for wastewater reuse in agriculture and aquaculture: Recommended revision based on new research evidence. Water Management, 19, 67-75.

Day, A. D., \& Tucker, T. C. (1997). Effects of treated wastewater on growth, fiber, protein and amino acid content of sorghum grain. Journal of Environmental Quality, 6(3), 325-327. https://doi.org/10.2134/ jeq1977.00472425000600030020x

Gholipour, S. (2013). Effect of drought stress on yield and yield components of safflower varieties in Khash city. Master's Degree in Agriculture, Payame Noor University, Zahedan Center, Iran.

Haghighati, A. (2010). Study on the effects of nitrogen and phosphorus fertilizers on the yield and oil content of safflower lines in drylands. Research Journal of Agronomy, 4, 57- 62. https://doi.org/10.3923/ rjagr.2010.57.62

Han, S. H., An, J. Y., Hwang, J., Kim, S. B., \& Park, B. B. (2016). The effects of organic manure and chemical fertilizer on the growth and nutrient concentrations of yellow poplar (Liriodendron tulipifera Lin.) in a nursery system. Forest Science and Technology, 12(3), 137-143. https://doi.org/10.1080/21580103.2015.1135827

Khan, M. J., Jan, M. T., \& Khan, K. (2013). Effect of organic and inorganic amendments on the heavy metal content of soil and wheat crop irrigated with wastewater. Sarhad Journal of Agriculture, 29(1), 49-57.

Khaskhoussy, K., Hachicha, M., Kahlaoui, B., MessoudiNefzi, B., Rejeb, A., Jouzdan, O., \& Arselan, A. (2013). Effect of treated wastewater on soil and corn in the Tunisian area. Journal of Applied Science Research, 9(1), 132-140.

Lebrun, M., Miard, F., Nandillon, R., Morabito, D., \& Bourgerie, S. (2021). Effect of biochar, iron sulfate and poultry manure application on the phytotoxicity of a former tin mine. International Journal of Phytoremediation, 23(12), 1222-1230. https://doi.org/10.1080/1522 6514.2021 .1889964

Mahmood, F., Khan, I., Ashraf, U., Shahzad, T., Hussain, S., Shahid, M., Abid, M., \& Ullah, S. (2017). Effects of organic and inorganic manures on maize and their residual impact on soil physico-chemica properties. Journal of Soil Science and Plant Nutrition, 17(1), 22-32. https://doi.org/10.4067/S0718-95162017005000002

McKeon, T., Hayes, D., Hildebrand, D., \& Weselake, R. (2016). Industrial Oil Crops (pp. 474). Academic Press and AOCS Press.

Mehraban, A. (2013). The Basis of Organic Fertilizers. (pp.108). LAP Lambert Academic Publishing.

Mohammad Rusan, M. J., \& Ayadi, M. (2006). Forage Yield and Nutrient Uptake as Influenced by Secondary Treated Wastewater. Journal of Plant Nutrition, 27(2), 351-365. https://doi.org/10.1081/PLN120027659

Nasri, M., Khalatbari, M., \& Hassanpour Darvishi, H. (2012). Effect of irrigation by domestic wastewater on quantity and quality characteristics of safflower (Carthamus tinctorius L.), alfalfa (Medicago sativa L.) and rose (Rosa hybrida L.) under lysimeter conditions. Advances in Environmental Biology, 6(7), 2190-2194.

National Research Council. (2005). Water Conservation, Reuse, and Recycling: Proceedings of an Iranian-American Workshop. Washington, DC: The National Academies Press.

Ohshiro, M., Hossain, M. A., Nakamura, I., Akamine, H., Takami, M., Bhowmik, C. P., \& Nose, A. (2016). Effects of soil types and fertilizers on growth, yield, and quality of edible Amaranthus tricolor lines in Okinawa, Japan. Plant Production Science, 19(1), 61-72. https://doi. org/10.1080/1343943X.2015.1128087

Pimentel, D. (1993). Economics and energies of organic and conventional farming. Journal of Agricultural and Environmental Ethics, 6, 53-60.

Rathke, G. W., Christen, O., \& Diepenbrok, W. (2005). Effect of nitrogen source and rate on productivity and quality of winter oilseed rape (Brassica napus L.) grown in different crop rotations. Field Crop Research, 94, 103-113. https://doi.org/10.1016/j.fcr.2004.11.010

Roozitalab, M. H., Siadat, H., \& Farshad, A. (2018). The Soils of Iran. (pp. 257). Springer International Press.

Sampaio, M. C., Santos, R. F., Bassegio, D., de Vasconselos, E. S., da Silveira, L., Barchinski Galant Lenz, N., Lewandoski, C. F., \& Tokuro, L. K. (2017). Effect of plant density on oil yield of safflower. African Journal of Agricultural Research, 12(25), 2147-2152. https:// doi.org/10.5897/AJAR2016.11370

Seyed Sharifi, R., Namvar, A., \& Seyed Sharifi, R. (2017). Grain filling and fatty acid composition of safflower fertilized with integrated nitrogen fertilizer and biofertilizers. Pesquisa Agropecuária Brasileira, 52(4), 236-243. https://doi.org/10.1590/S0100-204X2017000400003

Shahalam, A., Abu Zahra, B. M., \& Jaradat, A. (1998). Wastewater Irrigation Effect on Soil, Crop and Environment: a Pilot Scale Study at Irbid, Jordan. Water, Air, and Soil Pollution, 106, 425-445. https://doi. org/10.1023/A:1005046912234

Spellman, F. R. (2020). Water and wastewater treatment plant operations. (pp. 722). CRC Press.

Tavassoli, A., Ghanbari, A., Amiri, E., \& Paygozar, Y. (2010). Effect of municipal wastewater with manure and fertilizer on yield and quality characteristics of forage in corn. African Journal of Biotechnology, 9(17), 2515-2520.

Vollmann, J., \& Rajcan, I. (2009). Oil Crops. (pp. 584). New York: Springer Science \& Business Media.

Zeid, I. M., \& Abou El Ghate, H. M. (2007). Effect of Sewage Water on Growth, Metabolism and Yield of Bean. Journal of Biological Science, 7(1), 34-40. https://doi.org/10.3923/jbs.2007.34.40 